\title{
Kesalahan Terjemahan Konjungtor -te pada Kalimat Majemuk Bahasa Jepang: Kajian Struktur dan Makna
}

\author{
Saidatun Nishfullayli ${ }^{1}$, Wahyu Handayani Setyaningsih ${ }^{2}$ \\ Departemen Bahasa, Seni dan Manajemen Budaya Sekolah Vokasi UGM ${ }^{1,2}$ \\ saidatun.nishfullayli@ugm.ac.id ${ }^{1}$ \\ wahyu.hs@mail.ugm.ac.id ${ }^{2}$
}

\begin{abstract}
In translating Japanese compound sentences, generally, students still have difficulty in interpreting the meaning of the -te verb which functioned as a conjunction (-te conjunction) in compound sentences. Semantically, the te verb form has some meanings that can be distinguished based on the context of the sentence. Inaccuracy in determining the meaning of the -te conjunction can affect the results of translating compound sentences. In this research, the forms of te conjunction translation errors which causes the error in translating compound sentence will be elaborated. Data in this research taken from the translation of 'Haha no Tanjobi', which is one of the subtitles in the Rudolf Beethoven biography book titled Beetoben Kodomo Denki Zenshuu, translated by semester VI students of the Japanese Language Program, Vocational College, UGM. From the analysis, the causes of errors in translating conjunctions can be concluded as follows: learners do not understand the classification of the -te conjunctions' meaning, lack of mastery of Japanese and Indonesian compound sentence structures, and have not been able to understand the message/ meaning of each clause forming compound sentences in Japanese.
\end{abstract}

Keywords: error analysis, Japanese translation, compound sentences, conjunction, verbs

\section{INTISARI}

Dalam penerjemahan kalimat majemuk bahasa Jepang, umumnya pembelajar masih mengalami kesulitan dalam mengalihbahasakan makna verba bentuk -te yang berperan sebagai konjungtor (konjungtor -te) dalam kalimat majemuk. Secara semantis, verba bentuk te memiliki beberapa makna yang dapat dibedakan berdasarkan konteks kalimat. Ketidaktepatan dalam menentukan makna konjungtor -te dapat berpengaruh pada hasil penerjemahan kalimat majemuk. Dalam penelitian ini akan diuraikan tentang bentuk-bentuk kesalahan penerjemahan konjungtor -te yang berakibat pada terjadinya kesalahan penerjemahan kalimat majemuk. Data terjemahan berupa hasil terjemahan 'Haha no Tanjobi', yakni salah satu sub judul dalam buku biografi Rudolf Beethoven yang berjudul Beetoben Kodomo Denki Zenshuu, yang diterjemahkan oleh 20 orang mahasiswa semester VI Program Studi Bahasa Jepang Sekolah Vokasi UGM. Dari hasil analisis diketahui bahwa penyebab kesalahan penerjemahan konjungtor -te, antara lain: pembelajar kurang memahami klasifikasi makna konjungtor -te, kurang menguasai struktur kalimat majemuk bahasa Jepang dan bahasa Indonesia, serta belum mampu menangkap pesan/makna masingmasing klausa pembentuk kalimat majemuk bahasa Jepang.

Kata kunci: analisis kesalahan, penerjemahan bahasa Jepang, kalimat majemuk, konjungtor, verba-te 


\section{PENDAHULUAN}

Newmark (1988: 7) mendefinisikan penerjemahan sebagai sebuah kegiatan berupa usaha mengganti pesan maupun pernyataan tertulis, dari bahasa sumber (Bsu) ke dalam pesan atau pernyataan tertulis dalam bahasa sasaran (Bsa). Sementara itu secara lebih rinci, Larson (1988: 3) menjelaskan bahwa Penerjemahan adalah: (1) mempelajari leksikon, strutktur gramatikal, dan konteks budaya dari Bsu, (2) menganalisis Bsu untuk menemukan maknanya, dan (3) mengungkapkan kembali makna itu dengan menggunakan leksikon dan struktur gramatikal yang sesuai dalam Bsa dan konteks budaya penutur Bsa.

Mengacu pada definisi di atas, jelas bahwa penerjemah harus menguasai dua bahasa yang terlibat dalam kegiatan penerjemahan, terutama tentang leksikon dan struktur gramatika. Dalam kaitannya dengan kompetensi mahasiswa dalam hal menerjemahkan, pergeseran maupun kesalahan dalam menerjemahkan merupakan hal yang tidak terhindarkan. Akan tetapi, kesalahan dalam menerjemahkan dapat berakibat fatal karena makna dalam Bsu tidak dapat tersampaikan dengan akurat dalam Bsa.

Salah satu penyebab munculnya kesalahan dalam menerjemahkan adalah kurangnya penguasaan penerjemah terhadap gramatika Bsu maupun Bsa. Penguasaan gramatika yang rendah ini dikarenakan kurang optimalnya materi yang diberikan pada mata kuliah pendukung penerjemahan, baik itu pada mata pelajaran tata bahasa maupun mata pelajaran membaca. Sebagai contoh, mahasiswa tidak mampu menerjemahkan konjungtor te yang merupakan unsur penting dalam kalimat majemuk bahasa Jepang dikarenakan mahasiswa tidak memahami struktur dan makna kalimat majemuk dengan baik. Materi tentang kalimat majemuk tidak diberikan secara komprehensif dalam mata kuliah Tata Bahasa dan Membaca. Akibatnya, mahasiswa gagal dalam memahami pesan dalam Bsu yang berupa kalimat majemuk, sehingga hasil terjemahannya dalam Bsa menjadi tidak tepat.

Dalam kalimat majemuk, konjungtor (kata sambung) adalah penghubung antar klausa dalam kalimat majemuk. Dalam bahasa Indonesia, baik pada kalimat majemuk setara maupun bertingkat, konjungtor pada umumnya berbentuk leksikal, misalnya: dan, atau, lalu, kemudian, tetapi, agar, dengan. Dalam bahasa Jepang, konjungtor dalam kalimat majemuk umumnya berupa morfem terikat yang memiliki fungsi gramatikal sebagai konjungtor, salah satunya yakni morfem -te. Morfem -te merupakan gobi $^{1}$ dari verba bentuk $-t e^{2}$ yang dapat berfungsi sebagai konjungtor dalam kalimat majemuk, baik kalimat majemuk setara maupun bertingkat. Meskipun konjungtor -te berbentuk morfem terikat, namun ketika morfem -te berfungsi sebagai konjungtor, maka dalam penerjemahan bahasa Jepang ke Bahasa Indonesia, makna konjungtor -te tersebut harus diwujudkan dalam bentuk leksikal yang juga berfungsi sebagai konjungtor dalam kalimat majemuk Bahasa Indonesia, misalnya: 'kemudian', 'dan'.

Untuk dapat menerjemahkan konjungtor -te menjadi bentuk leksikal yang tepat dalam bahasa Indonesia, selain harus memahami variasi makna konjungtor -te, penerjemah juga harus menguasai struktur kalimat majemuk bahasa Jepang sekaligus mampu menangkap pesan yang ada dalam Bsu yang berupa kalimat majemuk tersebut. Sebagai contoh, kalimat Asa wa pan o tabete, koohi o nomimasu ${ }^{3}$ diterjemahkan dengan 'Pagi hari (saya) makan roti dan minum kopi'. Pemakaian "dan" tepat jika yang dimaksud adalah memberikan informasi tentang adanya dua kegiatan, tanpa memperhatikan apakah dua kegiatan tersebut harus dikerjakan

\footnotetext{
${ }^{1}$ Gobi adalah bentuk imbuhan sebagai hasil dari perubahan bentuk kata kerja.

${ }^{2}$ Verba -te adalah verba bentuk kamus yang diubah menjadi verba -te.

3 朝はパンを食べて、コーヒーを飲みます。

(Tomomatsu, 2007).
} 
berurutan atau tidak. Akan tetapi, jika konteks kalimat menghendaki dua kegiatan tersebut dikerjakan berurutan, maka konjungtor -te dapat diterjemahkan dengan "kemudian", sehingga menjadi 'Pagi hari saya makan roti, kemudian minum kopi'.

Penelitian ini dilakukan untuk mengidentifikasi terjadinya kesalahan penerjemahan konjungtor -te dari bahasa Jepang ke bahasa Indonesia. Teori analisis kesalahan (error analysis) yang digunakan dalam penelitian ini diharapkan dapat memberikan gambaran tentang bentukbentuk kesalahan penerjemahan konjungtor -te yang dilakukan oleh mahasiswa semester VI prodi Bahasa Jepang Sekolah Vokasi UGM. Selain itu, akan dijelaskan juga tentang hal-hal apa saja yang dimungkinkan menjadi penyebab munculnya kesalahan tersebut

Analisis kesalahan juga dapat berfungsi sebagai alat ukur kompetensi mahasiswa dalam penguasaan Tata Bahasa pada khususnya, dan kemampuan menerjemahkan pada umumnya. Dengan mengidentifikasi bentuk-bentuk kesalahan, baik mahasiswa maupun pengajar akan mendapatkan manfaatnya. Dengan mengetahui bentuk-bentuk kesalahan penerjemahan, mahasiswa dapat mengukur kelemahannya sendiri dalam menerjemahkan dan melakukan perbaikan. Bagi pengajar, bentuk-bentuk kesalahan tersebut akan memberikan kontribusi positif pada perbaikan materi pengajaran dalam beberapa mata kuliah yang terkait bidang penerjemahan, seperti Tata Bahasa dan Membaca.

\section{Tinjauan Pustaka}

\section{Analisis Kesalahan (error analysis)}

Setiap pembelajar bahasa kedua pasti mengalami kesalahan berbahasa dalam proses pembelajarannya. Perlu dilakukan analisis kesalahan untuk mengetahui kekurangan-kekurangan pembelajar dalam proses penguasaan bahasa keduanya tersebut. Analisis kesalahan juga bermanfaat bagi para pengajar dalam rangka meningkatkan kualitas pengajarannya, termasuk memperbaiki dan mengembangkan materi pengajarannya.

Menurut Ellis (dalam Tarigan, 1988), analisis kesalahan berbahasa adalah suatu prosedur yang digunakan oleh para pengajar dan peneliti, yang mencakup kegiatan pengumpulan sampel, identifikasi kesalahan-kesalahan, penjelasan penyebab kesalahan seperti hipotesis di awal, serta evaluasi keseriusan terhadap hasil analisis kesalahan.

Menurut Corder (dalam Tarigan, 1988), terdapat lima prosedur untuk melakukan analisis kesalahan berbahasa. Pertama, memilih korpus (sumber data) yang berupa sampel kesalahan berbahasa oleh responden. Kedua, mengenali bentukbentuk kesalahan dalam sumber data. Ketiga, mengklasifikasikan kesalahan, apakah kesalahan dalam bidang fonologi, morfologi, sintaksis, maupun semantik. Keempat, menjelaskan kesalahan, yakni sebuah upaya untuk menemukan faktorfaktor yang menyebabkan terjadinya kesalahan. Kelima, mengevaluasi kesalahan, yakni upaya untuk memanfaatkan hasil analisis kesalahan berbahasa dalam hal peningkatan pengajaran.

Terkait dengan identifikasi kesalahan, perlu dibedakan antara 'kesalahan' (error) dan 'kekeliruan' (mistakes). Kesalahan disebabkan karena kurangnya pengetahuan tentang kaidah bahasa (kompetensi) sehingga seseorang menghasilkan produksi bahasa yang menyimpang (bergeser). Kesalahan sering terjadi secara konsisten dan sistematis. 'Kesalahan' tidak dapat diperbaiki secara spontan oleh pembelajar karena kurangnya pengetahuan mereka tentang unsur bahasa terkait. Adapun 'kekeliruan' yakni ketidakmampuan pembelajar dalam masalah performansi yang disebabkan, misalnya karena lupa, grogi, sehingga tidak menghasilkan performa bahasa yang baik. 'Kekeliruan' dapat segera diperbaiki sendiri oleh pembelajar bersangkutan (Tarigan, 1988). 


\section{Konjungtor dalam Kalimat Majemuk}

Menurut aturan tata bahasa baku Bahasa Indonesia (Alwi, 2003), klausaklausa dalam kalimat majemuk dihubungkan oleh konjungtor yang berbentuk leksikal. Beberapa konjungtor yang lazim digunakan dalam kalimat majemuk setara, yaitu: dan, atau, kemudian, lalu, tetapi, bahkan, tidak hanya ..., tetapi.... Adapun konjungtor dalam kalimat majemuk bertingkat dibedakan berdasarkan jenis klausa adverbial, seperti: (1) konjungtor waktu: setelah, sesudah, sejak, (2) konjungtor syarat: jika, kalau, sehingga; (3) konjungtor pengandaian: andaikan, seandainya, (4) konjungtor tujuan: agar, supaya, (5) konjungtor konsesif: meskipun, sekalipun, (6) konjungtor pembandingan: seakan-akan, seolah-olah, (7) konjungtor sebab/alasan: sebab, karena, oleh karena, konjungtor akibat: sehingga, sampai, (8) konjungtor cara atau alat: dengan, tanpa.

Kalimat majemuk bahasa Jepang juga memiliki konjungtor. Berdasarkan bentuknya, konjungtor dapat digolongkan ke dalam empat (4) kelompok besar, yakni: (1) konjungtor berupa verba yang mengalami infleksi (perubahan bentuk imbuhan), dan akar verba (gokan), (2) partikel, seperti: $g a$, (3) kata sambung, baik yang biasa diletakkan di awal kalimat, maupun yang ditambahkan begitu saja di belakang verba, seperti: demo, soshite, noni, kara, node. Akan tetapi, pada umumnya konjungtor yang banyak ditemui dalam kalimat majemuk adalah berupa morfem terikat, salah satunya adalah bentuk -te yang dinilai memainkan peranan penting dalam pemaknaan kalimat majemuk (Minami, 2016).

\section{Konjungtor -te dalam Kalimat Majemuk Bahasa Jepang}

Konjungtor -te pada dasarnya adalah verba -te yang berfungsi menghubungkan klausa satu dengan klauasa lainnya dalam kalimat majemuk. Verba -te adalah verba bentuk kamus yang diubah menjadi verba dengan imbuhan berupa morfem -te.
Secara morfologis, verba -te terdiri dari gokan (akar verba) dan gobi (imbuhan yang bisa mengalami perubahan), dalam hal ini gobi berupa -te, -tte, -nde, -ite. Meskipun variasi gobi cukup banyak, tetapi dalam istilah linguistik tetap disebut verba -te.

Dalam linguistik bahasa Jepang, gobi digolongkan sebagai morfem. Dalam bahasa Jepang juga dikenal istilah morfem bebas dan morfem terikat. Morfem bebas umumnya berupa kata yang bisa berdiri sendiri dan bisa menjadi satu kalimat tunggal. Adapun kata yang tidak bisa berdiri sendiri disebut morfem terikat, misalnya partikel, adverbia, gokan (akar kata), dan gobi. Verba bentuk -te terdiri dari gokan dan gobi, yakni berupa morfem -te. Sebagai contoh, verba mite terdiri dari mi sebagai gokan dan -te sebagai gobi.

Morfem juga dapat dibedakan menjadi morfem isi (content morphem) dan morfem fungsi (function morphem). Morfem isi adalah morfem yang menunjukkan makna asli atau makna dasarnya, seperti nomina (nomina hon 'buku'; adverbia yoku 'sering', dan gokan dari verba). Morfem fungsi adalah morfem yang memperlihatkan fungsi gramatikalnya, misalnya: partikel, gobi, ajektiva, kopula, dan morfem penunjuk kala (Sutedi, 2003: 43). Dengan demikian, morfem -te pada verba bentuk te dapat digolongkan ke dalam morfem fungsi, yakni memiliki fungsi gramatikal sebagai konjungtor antar klausa dalam kalimat majemuk bahasa Jepang. Untuk selanjutnya dipakai istilah konjungtor -te untuk merujuk pada verba bentuk -te yang berperan sebagai konjungtor.

Dalam kaitannya dengan makna konjungtor -te pada kalimat majemuk, Nitta (2008) menjelaslan ada delapan (8) kelompok makna yang dimiliki konjungtor -te, yaitu:

1. menyatakan beberapa kegiatan (並列 ). Subyek pada klausa pertama dan kedua bisa sama ataupun berbeda. 
contoh (1)

あしたはスーパーへ行って、郵便局へ 行きます。

Ashita wa suupaa e itte, yuubinkyoku e ikimasu.

Besok saya pergi ke supermarket dan ke kantor pos.

2. menyatakan perbandingan (対比) contoh (2)

昨日は快晴だったのとうってかわって 今朝は激しい雨が降っている。

Kinou wa kaisei datta no tootte kawatte, kesa wa hageshii ame ga futte iru.

(2a) Kemarin hari sangat cerah, tetapi tadi pagi hujan sangat deras.

(2b) Berbeda dengan kemarin yang sangat cerah, tadi pagi hujan sangat deras.

3. menyatakan makna perkiraan（前触れ） $\operatorname{contoh}(3)$

問題が一つあって、父は英語が話せな いのである。

Mondai ga hitotsu de atte, chichi wa eigo o hanasenai no de aru.

Ada satu masalah yaitu ayah tidak bisa berbahasa Inggris.

4. menyatakan tahapan pelaksanaan aktivitas (継起)

contoh (4)

デパートへ行って、靴を買った。

Depaato e itte, kutsu o katta.

(Saya) pergi ke department store dan membeli sepatu (di sana).

5. menyatakan sebab akibat（原因・理由） contoh (5)

風邪をひいて、仕事を休んだ。

Kaze o hiite, shigoto o yasunda.

Karena (saya) masuk angin, (saya) tidak masuk kerja.

6. menyatakan dua kegiatan yang berlawanan (逆接)

contoh (6)

分かっていていわないなんて、ひど い。 wakatte ite wakatte inainante, hidoi.

Mengerti tapi mengaku tidak mengerti, keterlaluan!

7. menyatakan tingkatan/ordering (順接 条件)

contoh (7)

参加者は、幹事を入れて 8 人だ。

Sankasha wa, kanji o irete hachinin da.

Pesertanya berjumlah 8 orang termasuk sekretaris.

8. Menyatakan adanya penyertaan, yakni dua kegiatan yang dilakukan bersamaan atau di waktu yang bersamaan（付带状況）

contoh (8)

胸を張って、堂々と行進した。

Mune o hatte, dou-dou to shinkou shita.

(Aku) berbaris maju dengan tegap.

Adapun menurut Tomomatsu (2007: 159), setidaknya ada lima (5) makna konjungtor te secara umum. Makna ini harus dileksikalkan jika konjungtor -te diterjemahkan ke dalam bahasa Indonesia. Berikut adalah makna verba -te ketika berperan sebagai konjungtor dalam kalimat majemuk.

1) Menyatakan beberapa kegiatan (並列)

Contoh (9)

朝はパンを食べて、コーヒーを飲みま す。

Asa wa pan o tabete, koohii o nomimasu (9a) Pada pagi hari (saya) makan, kemudian minum kopi.

(9b) Pada pagi hari saya makan dan minum kopi.

2) Menyatakan tahapan pelaksanaan aktivitas（継起）

Contoh (10)

電気をけして、部屋を出ます。

Denki o keshite, heya o demasu.

(10a) (Saya) mematikan lampu kemudian keluar kamar.

(10b) (Saya) mematikan lampu lalu keluar kamar. 
Kalimat majemuk di atas memperlihatkan adanya dua kegiatan yang berkaitan. Kegiatan pertama harus dipenuhi dulu sebelum melakukan kegiatan kedua. Dengan demikian, kegiatan mematikan lampu kamar adalah tahap yang dilakukan sebelum pembicara keluar kamar.

3) Menyatakan perbandingan（対比）

Contoh (11)

私は昼は学校で勉強して、夜は英語学 校で英語を教えています。

Watashi wa hiru wa gakkou de benkyou shite, yoru wa eigo-gakkou de eigo o oshiete imasu.

Pada siang hari saya belajar di kampus, sementara itu pada malam hari (saya) mengajar bahasa Inggris di sekolah vokasi bahasa Inggris.

4) Menyatakan adanya dua kegiatan yang dilakukan bersamaan (付帯状況)

Contoh (12)

$\mathrm{CD}$ を聞いて、発音の練習をします。

CD o kiite, hatsuon o renshuu shimasu.

(Saya) berlatih pengucapan dengan cara mendengarkan CD.

5) Menyatakan alasan atau sebab (原因 理由), yang mana klausa kedua biasanya memperlihatkan makna 'repot, bingung, atau terjadi hal-hal yang tidak diinginkan)

Contoh (13)

用事があって、会には参加できません。 Youji ga atte, kai ni wa sanka dekimasen.

(13a) (Saya) tidak bisa menghadiri pertemuan karena ada keperluan.

(13b) Karena ada keperluan, (saya) tidak bisa menghadiri pertemuan.

Dari contoh-contoh penerje-mahan konjungtor -te di atas, terlihat bahwa konjungtor -te dapat diterjemahkan ke dalam beberapa bentuk leksikal, dengan makna yang berbeda-beda, tergantung konteks kalimat (dalam hal ini dengan melihat hubungan makna antar klausa, apakah hubungan penambahan, alasan, sebab, dan sebagainya). Oleh karena itu, selain memahami variasi makna verba -te yang berperan sebagai konjungtor, penerjemah perlu menguasai struktur dan makna kalimat majemuk. Tanpa pemahaman makna, penerjemah akan menemui kesulitan untuk menentukan hubungan makna antar klausa, sehingga berakibat pada kegagalan menerjemahkan konjungtor -te.

\section{METODE PENELITIAN}

Penelitian tentang analisis kesalahan penerjemahan konjungtor te ini menggunakan metode kualitatif. Setelah diketahui prosentase jumlah kesalahan dalam menerjemahkan konjungtor -te, akan dipaparkan tentang variasi bentuk leksikal penerjemahan konjungtor -te dalam bahasa Indonesia. Selanjutnya, akan diuraikan juga tentang bentuk-bentuk kesalahan penerjemahan konjungtor -te dikaitkan dengan pemahaman responden terhadap makna/pesan yang ada dalam kalimat majemuk. Terakhir adalah pemaparan tentang beberapa hal yang dimungkinkan menjadi penyebab munculnya kesalahan kesalahan tersebut.

Sumber data penelitian ini adalah hasil terjemahan sebuah teks pendek berjudul 'Haha no Tanjobi yang merupakan satu sub judul dalam buku biografi Bethoven yang berjudul Beetoben Kodomo Denki Zenshuu Teks tersebut diterjemahkan oleh 20 orang mahasiswa semester VI yang telah menempuh mata kuliah Penerjemahan I dan II, dan 17 orang dari mereka juga telah menyelesaikan Tugas Akhir (TA) penerjemahan.

Prosedur penelitian yang dilakukan mengacu pada tahapan penelitian Analisis Kesalahan yang disampaikan oleh Corder (dalam Tarigan, 1988). Sebelum melakukan analisis, dilakukan tahap persiapan yang dimulai dari pengumpulan sampel data. Kegiatan pengambilan data dilakukan sebanyak satu kali dengan total waktu menerjemahkan maksimal 4 jam. Mahasiswa diperbolehkan membuka kamus dan melakukan pencarian informasi 
dengan search engine untuk mendapatkan informasi apapun terkait teks yang akan diterjemahkan.

Selanjutnya, sampel data yang berupa hasil terjemahannya kalimat majemuk mengandung konjungtor -te, dikelompokkan dan diberi kode (misalnya, kode A.1 adalah terjemahan kalimat majemuk ke-1 yang diterjemahkan oleh responden nomor satu; dan seterusnya). Dari 27 kalimat dalam teks yang diterjemahkan, 10 di antaranya adalah kalimat majemuk dengan konjungtor -te. Selanjutnya, seluruh hasil penerjemahan dikelompokkan kembali berdasarkan makna konjungtor -te agar dapat diidentifikasi dengan mudah jenis-jenis kesalahan, variasi penerjemahan, serta prosentase jumlah penerjemahan yang tidak tepat.

Berikutnya dilakukan tahap analisis data dengan melakukan: (1) identifikasi bentuk-bentuk kesalahan penerjemahan konjungtor -te; (2) mengklasifikasikan kesalahan, apakah kesalahan penerjemahan konjungtor te atau kesalahan penerjemahan kalimat majemuk secara keseluruhan; (3) menjelaskan kesalahan, yakni menguraikan faktor-faktor yang menyebabkan terjadinya kesalahan; (4) mengevaluasi kesalahan, langkah perbaikan apa saja yang dapat diambil setelah mengetahui bentuk-bentuk kesalahan dan faktor-faktor penyebabnya.

\section{HASIL DAN PEMBAHASAN}

Sebanyak 20 mahasiswa menerjemahkan keseluruhan kalimat dalam teks yang terdiri dari 27 kalimat. Sebanyak 10 kalimat dari keseluruhan kalimat tersebut adalah berupa kalimat majemuk yang mengandung konjungtor -te. Dari kesepuluh kalimat majemuk tersebut teridentifikasi lima (5) makna konjungtor te, yakni:

a. Konjungtor -te menyatakan adanya beberapa kegiatan（並立） sejumlah 2 kalimat. b. Konjungtor -te menyatakan tahapan/prosedur (継起) sejumlah 3 kalimat.

c. Konjungtor -te menyatakan perbandingan (対比) sejumlah 1 kalimat.

d. Konjungtor -te menyatakan dua kegiatan yang dilakukan dalam satu waktu (付带状況) sejumlah 3 kalimat.

e. Konjungtor -te menyatakan sebab (原 因・理由) sejumlah 1 kalimat.

Berikut adalah uraian atas hasil analisis terhadap penerjemahan konjungtor -te dalam teks data.

\section{Bentuk-bentuk Kesalahan Penerjemah- an Konjungtor -te}

Konjungtor -te dapat diterjemahkan dengan beberapa variasi terjemahan, tergantung konteks kalimatnya. Di sini responden harus memahami konteks tersebut untuk dapat menerjemahkan bentuk konjungtor -te menjadi konjungtor berbentuk leksikal dalam Bsa, yang maknanya juga sesuai dengan pesan yang terkandung dalam Tsu. Berikut adalah presentase jumlah kesalahan penerjemahan konjungtor -te yang dikelompokkan berdasarkan makna konjungtor -te.

Berdasarkan Tabel 1, terlihat bahwa dari 200 kalimat majemuk mengandung konjungtor -te, hanya $22 \%$ kalimat yang diterjemahkan dengan tepat oleh responden. Sementara itu, sebanyak $49 \%$ responden menerjemahkan dengan salah atau tidak tepat, dan $29 \%$ responden memilih cara aman dengan cara tidak menerjemahkan konjungtor -te tersebut menjadi bentuk leksikal yang tepat dalam Bsa. Dengan kata lain, hampir $80 \%$ kalimat tidak berhasil diterjemahkan dengan tepat, dan hanya $22 \%$ yang berhasil diterjemahkan dengan baik. Hal ini menunjukkan bahwa kemampuan responden dalam menerjemahkan kalimat majemuk, khususnya konjungtor -te, masih sangat 
rendah. Bentuk kesalahan atau ketidaktepatan dalam menerjemahkan konjungtor te tentu dengan mempertimbangkan kesalahan atau

ketidaktepatan penerjemahan kalimat majemuk. Secara umum, kesalahan yang tercakup dalam tabel 1 terdiri dari kesalahan semantis dan sintaktis.

Tabel 1. Rekap Hasil Terjemahan Masing-masing Makna Konjungtor -te

\begin{tabular}{|l|c|c|c|c|}
\hline \multicolumn{1}{|c|}{ Makna konjungtor -te } & $\begin{array}{c}\text { Jumlah } \\
\text { Kalimat }\end{array}$ & $\begin{array}{c}\text { Terjemahan } \\
\text { Benar/Tepat }\end{array}$ & $\begin{array}{c}\text { Terjemahan } \\
\text { Salah/Tidak } \\
\text { tepat }\end{array}$ & $\begin{array}{c}\text { Tidak } \\
\text { Diterjemah- } \\
\text { kan }\end{array}$ \\
\hline $\begin{array}{l}\text { Menyatakan beberapa kegiatan yang } \\
\text { berurutan (並立) }\end{array}$ & 40 & 10 & 7 & 23 \\
\hline $\begin{array}{l}\text { Menyatakan tahapan pelaksanaan kegiatan } \\
\text { (継起) }\end{array}$ & 60 & 21 & 30 & 9 \\
\hline Menyatakan perbandingan (対比) & 20 & 0 & 14 & 6 \\
\hline $\begin{array}{l}\text { Menyatakan dua kegiatan yang dikerjakan } \\
\text { dalam satu waktu (付帯状況) }\end{array}$ & 60 & 12 & 39 & 9 \\
\hline $\begin{array}{l}\text { Menyatakan sebab } \\
\text { (原因・理由) }\end{array}$ & 20 & 1 & 8 & 11 \\
\hline TOTAL KALIMAT & 200 & 44 & 98 & 58 \\
\hline PROSENTASE (\%) & & 22 & 49 & 29 \\
\hline
\end{tabular}

Berdasarkan hasil analisis, kesalahan penerjemahan konjungtor -te disebabkan oleh kurangnya pemahaman mahasiswa terhadap kalimat majemuk, baik secara sintaktis maupun semantis. Hal itu ditengarai juga menjadi penyebab munculnya kesalahan dalam menerjemahkan kalimat majemuk. Berikut akan diuraikan bentuk-bentuk kesalahan yang berakibat pada kesalahan penerjemahan konjungtor $-t e$.

\section{1) Kesalahan dalam memaknai verba bentuk pasif}

Kesalahan menerjemahkan klausa penyusun kalimat majemuk, karena mahasiswa tidak berhasil menangkap makna dalam klausa tersebut, memicu kesalahan dalam penerjemahan konjungtor -te yang menjadi penghubung antar klausa. Terlebih jika klausa yang diterjemahkan berupa kalimat pasif, sebagian besar mahasiswa tidak berhasil menerjemahkan bentuk pasif ini dengan baik, sehingga terjemahan konjungtor -te juga tidak tepat.

Pada (A.1), mahasiswa tidak memahami makna kata irerareru, yakni bentuk pasif dari kata ireru 'memasukkan'.
Seharusnya irerareru dimaknai dengan 'dimasukkan'. Karena obyek yang dimasukkan adalah manusia, dalam hal ini adalah ibu yang dihormati, sehingga haha wa shinshitsu ni irerareru dapat diterjemahkan dengan 'ibu diminta masuk ke dalam kamar tidur'. Klausa kedua yakni nekasarete shimaimasu seharusnya diterjemahkan dengan 'ibu terbaring', atau 'ibu tertidur'. Di sini mahasiswa tidak memperhatikan bentuk pasif kata nekasareru sehingga hanya diterjemahkan dengan kata 'berbaring' yang merupakan terjemahan bentuk verba aktif nekasu. Karena makna kedua klausa tersebut tidak dapat ditangkap denga benar, sehingga mahasiswa cenderung menerjemahkan konjungtor -te dengan kata 'dan' karena yang penerjemah memaknai 'masuk kamar dan berbaring adalah dua buah kegiatan yang berurutan. Padahal seharusnya, 'masuk kamar' dimaknai sebagai tahapan yang harus ada sehingga ibu bisa tertidur. Dari penjelasan tersebut terbukti bahwa ketidakmampuan menangkap pesan dalam Tsu dapat berakibat pada pergeseran makna/pesan. 
Kegagalan mahasiswa dalam memahami makna klausa verbal bentuk pasif juga terlihat pada data (K.8). Klausa otousan $n i$ iwarete dipahami sebagai bentuk aktif, bukan pasif. Seharusnya klausa tersebut diterjemahkan dengan 'diminta oleh ayah', bukan 'ayah mengatakan'. Jika pesan yang ditangkap tidak tepat, kemungkinan besar akan terjadi ketidaktepatan pula dalam menerjemahkan konjungtor -te. Secara semantis, bentuk leksikal konjungtor -te dalam kalimat majemuk bahasa Indonesia ditentukan secara semantis, yakni dengan terlebih dahulu memahami pesan dan konteks cerita.
Ketidakmampuan dalam menghubungkan makna antar klausa mendorong mahasiswa untuk cenderung menerjemahkan konjungtor -te hanya dengan bentuk-bentuk leksikal yang familiar bagi mereka saja, seperti dan, lalu, kemudian; atau mencari jalan aman dengan tidak meleksikalkan konjungtor -te ketika menerjemahkannya dalam Bsa. Mereka hanya menjajarkan beberapa kegiatan yang dimaksud dalam klausa dan memberi tanda jeda berupa koma atau titik di antara klausa-klausa tersebut, mengikuti teks aslinya dalam bahasa Jepang.

\section{Tabel 2 Contoh Kesalahan dalam Memaknai Verba Bentuk Pasif}

\begin{tabular}{|c|c|c|c|c|}
\hline No. & $\begin{array}{l}\text { Makna/Fungsi } \\
\text { Konjungtor -te }\end{array}$ & Tsu & Tsa & Usulan Terjemahan \\
\hline A. 1 & $\begin{array}{l}\text { Menyatakan dua } \\
\text { kegiatan yang } \\
\text { dikerjakan dalam } \\
\text { satu waktu } \\
\text { (付帯状況) }\end{array}$ & $\begin{array}{l}\text { 今日はもう夕方から、おか } \\
\text { あさんはしんしつにいれられて、 } \\
\text { ねかされてしまいます。 } \\
\text { Kyou wa mou yuugata kara, } \\
\text { okaasan wa shinshitsu ni } \\
\text { irerarete, negasarete shimaimasu }\end{array}$ & $\begin{array}{l}\text { Karena hari sudah } \\
\text { malam, Ibu masuk } \\
\text { ke kamar tidur } \\
\text { dan berbaring } \\
\text { untuk beristirahat. }\end{array}$ & $\begin{array}{l}\text { Karena hari sudah } \\
\text { petang, ibu diminta } \\
\text { untuk berada di } \\
\text { kamar, sehingga Ibu } \\
\text { bisa tertidur. }\end{array}$ \\
\hline K.8 & $\begin{array}{l}\text { Menyatakan sebab } \\
\text { (原因・理由) }\end{array}$ & $\begin{array}{l}\text { 「ルードウィッヒ、さあ、あの曲 } \\
\text { をおやり。」と、おとうさんにも } \\
\text { 言われて、やっとクラブサンに向 } \\
\text { かって弾(ひ)きだしたのはバッ } \\
\text { の曲でした。 } \\
\text { “Ruudowihhi san, saa, ano kyoku } \\
\text { o oyari” to, otousan ni mo } \\
\text { iwarete, yatto kurabusan ni } \\
\text { mukatte, hikidashita no wa Baffu } \\
\text { no kyoku deshita. }\end{array}$ & $\begin{array}{l}\text { "Nah, Beethoven } \\
\text { mainkan } \\
\text { nadanya." kata } \\
\text { sang ayah juga, } \\
\text { lalu Beethoven } \\
\text { menghadap } \\
\text { clavecin dan } \\
\text { memainkan nada } \\
\text { Bach }\end{array}$ & $\begin{array}{l}\text { "Ayo Ludwigh, } \\
\text { mainkan lagu itu". } \\
\text { Karena ayahnya } \\
\text { memintanya } \\
\text { demikian, maka } \\
\text { Ludwigh menghadap } \\
\text { Clavecin, dan } \\
\text { komposisi yang } \\
\text { dimainkannya adalah } \\
\text { Bach. }\end{array}$ \\
\hline
\end{tabular}

\section{2) Kesalahan dalam membedakan makna kata 'dan' dan 'lalu'}

Dalam bahasa Indonesia, konjungtor lalu lebih memperlihatkan adanya penekanan waktu dibanding konjungtor 'dan' yang hanya sekedar menggabungkan dua hal atau lebih. Karena responden tidak dapat membedakan makna dan dan lalu, kedua kata itu dipakai secara acak, sehingga hasil terjemahan konjungtor -te kurang tepat. Dalam contoh berikut ini terlihat juga bahwa responden tidak memahami bentuk-bentuk klausa perbandingan dalam kalimat majemuk bahasa Jepang.
Pada data (D.2), konjungtor -te yang diterjemahkan dengan kata lalu dinilai kurang tepat karena dalam Tsu tidak terlihat adanya perbedaan waktu antara klausa pertama dan kedua. Adapun pemakaian dan pada (D.7) sebenarnya berterima, namun tidak terlihat nuansa perbandingan keadaan yang tersirat dalam dua klausa, yakni keadaan di kamar dan keadaan di atas meja. Dalam penerjemahan kalimat $\mathrm{D}$ ini tidak satu pun mahasiswa yang menerjemahkan dengan tepat. 
Tabel 3 Contoh Kesalahan Dalam Membedakan Makna Kata 'Dan' Dan 'Lalu'

\begin{tabular}{|c|c|c|c|c|}
\hline No. & $\begin{array}{c}\text { Makna/ } \\
\text { Fungsi } \\
\text { Konjungtor } \\
-t e\end{array}$ & Tsu & Tsa & Usulan Terjemahan \\
\hline D. 2 & \multirow[t]{2}{*}{$\begin{array}{l}\text { Menyatakan } \\
\text { perbandingan } \\
\text { (対比) }\end{array}$} & \multirow{2}{*}{$\begin{array}{l}\text { へやには、クラブサンがお } \\
\text { かれ、テーブルの上には、 } \\
\text { ごちそうもすっかり並べら } \\
\text { れました。 } \\
\text { Heya ni wa, kurabusan ga } \\
\text { okare, teeburu no ue ni wa, } \\
\text { gochisou mo sukkari } \\
\text { naraberaremashita. }\end{array}$} & $\begin{array}{l}\text { Di ruangan sudah } \\
\text { diletakkan clavecin lalu } \\
\text { diatas meja terdapat } \\
\text { masakan yang sudah } \\
\text { tertata rapi. }\end{array}$ & \multirow[t]{2}{*}{$\begin{array}{l}\text { Di dalam ruangan } \\
\text { diletakkan Clavecin, } \\
\text { sementara di atas meja, } \\
\text { hidangan pun sudah } \\
\text { tertata rapi. }\end{array}$} \\
\hline D.7 & & & $\begin{array}{l}\text { Di ruangan itu terdapat } \\
\text { clavecin dan di atas meja } \\
\text { hidangan pun semuanya } \\
\text { sudah ditata. }\end{array}$ & \\
\hline
\end{tabular}

\section{3) Kesalahan dalam menyusun kembali} hasil terjemahan ke dalam bentuk kalimat majemuk bahasa Indonesia

Untuk kalimat majemuk yang terdiri lebih dari dua klausa, atau kalimat majemuk yang diperluas salah satu unsur sintaktisnya, umumnya mahasiswa tidak berhasil menerjemahkan dengan tepat, seperti terlihat dalam contoh berikut. Tidak hanya itu saja, kalimat majemuk yang panjang juga menyulitkan mereka untuk menangkap pesan yang dimaksud dalam Tsu, sehingga rentan terjadi pergeseran makna/pesan.

Pada kalimat F, konjungtor -te seharusnya diterjemahkan dengan kata setelah, karena kalimat majemuk menunjukkan dua hal yang terjadi berurutan, yaitu 'duduk di kursi' dan 'terbelalak kaget'. Namun, kalimat ini menjadi kompleks karena keterkejutan dan kebahagiaan sang ibu juga dilukiskan dengan tiga kata, yakni amarinomigotosa ni, odoroku yara, ureshiku yara. Selain itu, ditambahkan pula hal yang menjadi penyebab ibu bahagia dan terkejut, yakni karena melihat ruangan yang indah dan hidangan yang tertata rapi di atas meja. Akibatnya, kalimat menjadi lebih kompleks dan panjang.

Oleh karena mahasiswa tidak berhasil memahami pesan dalam kalimat majemuk dan gagal menyusun pesan tersebut secara logis, maka pada data (F.1), mahasiswa tidak menerjemahkan konjungtor -te dan hanya menjajarkan beberapa klausa tersebut tanpa memberikan konjungtor sebagai penghubung antar klausa. Adapun data (F.2) menunjukkan adanya pergeseran makna kalimat majemuk. Seharusnya, 'ruangan yang dihias' adalah penyebab ibu menjadi bahagia, tetapi dalam hasil terjemahan terlihat bahwa 'ruangan yang dihias' dijadikan sebagai tempat ibu membelalakkan mata karena kaget dan bahagia. Kesalahan ini dimungkinkan terjadi karena mahasiswa tidak memperhatikan partikel yang menyertai kata kazarareta heya 'ruangan yang dihias', dan ini dapat digolongkan dalam kesalahan sintaktis.

Kesalahan penerjemahan konjungtor -te dalam kalimat majemuk juga disebabkan oleh ketidakmampuan mahasiswa dalam menentukan subyek kalimat. Subyek kalimat bahasa Jepang yang umumnya dilesapkan tidak mudah diidentifikasi oleh mahasiswa karena mereka belum memahami fungsi partikel sesuai konteks kalimat. Akibatnya adalah konjungtor te tidak berhasil diterjemahkan dengan tepat. Kesalahan tersebut terlihat penjelasan berikut ini.

Terlihat pada data (I.5) dan (I.13), mahasiswa tidak mampu tidak memperhatikan partikel-partikel yang seharusnya membantu pemahaman mereka untuk dapat menentukan masing-masing fungsi (subyek, predikat, obyek) dalam kalimat. Subyek dalam kalimat bahasa Jepang tidak pernah diikuti oleh partikel $n i$ 
atau $o$ seperti hasil terjemahan di atas. Dengan demikian, meskipun subyek (dalam hal ini subyek sebagai pelaku kegiatan) tidak disebutkan secara eksplisit dalam teks, pembaca dapat menentukan subyek (pelaku) dengan memperhatikan partikel dan konteks kalimat. Dari 20 hasil terjemahan kalimat I, sebanyak 18 mahasiswa melakukan kesalahan penerjemahan. Dengan demikian secara tidak langsung kesalahan sintaktis disebabkan oleh rendahnya pemahaman mahasiswa terhadap fungsi partikel sebagai penentu fungsi (subyek, predikat, obyek) dalam kalimat.

Tabel 4 Contoh Kesalahan dalam Menyusun Kalimat Majemuk

\begin{tabular}{|c|c|c|c|c|}
\hline No. & $\begin{array}{l}\text { Makna/Fungsi } \\
\text { Konjungtor -te }\end{array}$ & Tsu & Tsa & $\begin{array}{c}\text { Usulan } \\
\text { Terjemahan }\end{array}$ \\
\hline F.1 & \multirow[t]{2}{*}{$\begin{array}{l}\text { Menyatakan } \\
\text { beberapa } \\
\text { kegiatan yang } \\
\text { berurutan } \\
\text { (継起) }\end{array}$} & $\begin{array}{l}\text { そして、一番りっぱない } \\
\text { すにこしをおろして、飾 } \\
\text { られたへやの中や、ごち } \\
\text { そうの並んだテーブルの } \\
\text { 上を見ると、あまりのみ } \\
\text { ごとさに、おどろくや } \\
\text { ら、うれしくなるやら、 } \\
\text { すっかり目をみはってし } \\
\text { まいます。 }\end{array}$ & $\begin{array}{l}\text { Lalu, Ibu duduk di kursi } \\
\text { terbaik, di dalam ruangan } \\
\text { yang dihiasi, lalu ketika } \\
\text { melihat di atas meja yang } \\
\text { berjejer makanan, terdapat } \\
\text { banyak hiasan, Ibu kaget dan } \\
\text { juga menjadi senang, matanya } \\
\text { benar-benar terbelalak. }\end{array}$ & \multirow[t]{2}{*}{$\begin{array}{l}\text { Kemudian, setelah } \\
\text { ibu duduk di kursi } \\
\text { yang paling bagus, } \\
\text { beliau terbelalak } \\
\text { kaget bercampur } \\
\text { senang dan bahagia } \\
\text { begitu melihat } \\
\text { ruangan yang dihias } \\
\text { dan hidangan lezat } \\
\text { yang tertata rapi di } \\
\text { atas meja. }\end{array}$} \\
\hline F. 2 & & $\begin{array}{l}\text { Soshite, ichiban rippa na } \\
\text { isu ni koshi o oroshite, } \\
\text { kazarareta heya no naka } \\
\text { ya, gochisou no naranda } \\
\text { teeburu no ue miru to, } \\
\text { Amari nomigotosa ni, } \\
\text { odoroku yara, ureshiku } \\
\text { naru yara, sukkari me o } \\
\text { mihatte shimaimasu. }\end{array}$ & $\begin{array}{l}\text { Kemudian, ibu ingin terkejut, } \\
\text { ibu menjadi gembira, ia } \\
\text { benar-benar membelalakkan } \\
\text { matanya di dalam ruangan } \\
\text { yang sudah di hias, ketika } \\
\text { melihat makanan yang sudah } \\
\text { tertata diatas meja terlalu } \\
\text { banyak kemegahan. }\end{array}$ & \\
\hline
\end{tabular}

Tabel 5 Contoh Kesalahan dalam Menentukan Subyek Kalimat

\begin{tabular}{|c|c|c|c|c|}
\hline No. & $\begin{array}{l}\text { Makna/Fungsi } \\
\text { Konjungtor -te }\end{array}$ & Tsu & Tsa & $\begin{array}{c}\text { Usulan } \\
\text { Terjemahan } \\
\end{array}$ \\
\hline I.5 & \multirow{2}{*}{$\begin{array}{l}\text { Menyatakan } \\
\text { dua kegiatan } \\
\text { yang dikerjakan } \\
\text { dalam satu } \\
\text { waktu （付帯 } \\
\text { 状況） }\end{array}$} & \multirow{2}{*}{$\begin{array}{l}\text { 今日まねいたお客さん } \\
\text { に、しきりとお酒やごち } \\
\text { そうをすすめてまわって } \\
\text { います。 } \\
\text { Kyou maneita okyaku san } \\
\text { ni, shikiri to osake ya } \\
\text { gochisou o susumete } \\
\text { mawatte imasu. }\end{array}$} & $\begin{array}{l}\text { Tamu yang diundang hari } \\
\text { ini, ditawarkan makanan } \\
\text { dan arak berkali-kali. }\end{array}$ & \multirow{2}{*}{$\begin{array}{l}\text { (Ayah) berkeliling } \\
\text { sambil berkali-kali } \\
\text { menawarkan } \\
\text { hidangan dan sake } \\
\text { kepada para tamu } \\
\text { yang hadir hari ini. }\end{array}$} \\
\hline I.13 & & & $\begin{array}{l}\text { Hari ini, wine dan makanan } \\
\text { terus disajikan kepada tamu } \\
\text { yang telah diundang. }\end{array}$ & \\
\hline
\end{tabular}

Berdasarkan uraian di atas, kurangnya pemahaman mahasiswa tentang kalimat majemuk bahasa Jepang, termasuk tentang fungsi konjungtor, terlihat sebagai penyebab umum ketidaktepatan penerjemahan kalimat majemuk. Dari hasil analisis dapat diuraikan tiga hal yang berkontribusi pada ketidaktepatan penerjemahan konjungtor -te dari bahasa Jepang ke bahasa Indonesia.

a. Mahasiswa belum mampu memahami pesan/makna dalam klausa-klausa penyusun kalimat majemuk Tsu, sehingga terjadi kegagalan ketika menerjemahkan konjungtor -te ke dalam Bsa. Ketidakmampuan dalam menangkap pesan ini salah satunya 
terjadi karena mereka tidak memahami makna kata ataupun frasa yang membentuk klausa yang dimaksud. Selain itu, rendahnya pemahaman terhadap fungsi partikel sebagai penentu fungsi subyek, predikat, obyek, keterangan, penyerta, pelengkap; juga berkontribusi ketidakmampuan rmahasiswa memahami makna klausa tersebut.

b. Mahasiswa belum memahami variasi makna/fungsi konjungtor te dalam kalimat majemuk secara optimal.

Dari hasil terjemahan terlihat kecenderungan mahasiswa untuk menerjemahkan konjungtor -te hanya dengan kata: dan, lalu, kemudian; atau memilih jalan aman dengan hanya menyertakan tanda koma atau titik, tanpa menerjemahkan konjungtor -te tersebut. Hal ini menunjukkan bahwa mereka tidak memiliki pengetahuan yang cukup tentang variasi makna verba -te yang berperan sebagai konjungtor dalam kalimat majemuk.

Selain makna konjungtor -te, mahasiswa juga tidak memahami adanya perbedaan bentuk konjungtor antara bahasa Jepang dan bahasa Indonesia. Konjungtor dalam bahasa Jepang yang berbentuk morfem luput untuk diidentifikasi sebagai konjungtor, sehingga dianggap sebagai verba bentuk te saja, bukan sebagai konjungtor yang memiliki makna dan harus diubah ke bentuk leksikal jika ingin diterjemahkan ke dalam bahasa Indonesia.

c. Penerjemah belum menguasai struktur kalimat majemuk bahasa Jepang dan bahasa Indonesia

Karena tidak menguasai struktur kalimat majemuk bahasa Jepang, responden kesulitan dalam memahami makna/pesan dalam Tsu. Keadaan tersebut dipersulit lagi dengan ketidakmampuan mereka mengalihbahasakan Tsu ke dalam bentuk kalimat majemuk bahasa Indonesia secara baik dan benar.
Dalam proses penguasaan L2 (bahasa asing), seorang pembelajar akan mencari kesamaan struktur kalimat L2 dalam L1 yang dikuasainya. Responden penelitian yang merupakan pembelajar bahasa Jepang memahami bahwa struktur kalimat tunggal bahasa Jepang berbeda dengan bahasa Indonesia (Bahasa Indonesia berstruktur SVO, bahasa Jepang berstruktur SOV). Akan tetapi, ketika harus menerjemahkan kalimat majemuk, terutama kalimat majemuk dengan lebih dari dua klausa, responden kesulitan untuk menerjemahkannya dalam Bsa. Terlebih jika kalimat majemuk tersebut diperluas salah satu unsur sintaktisnya sehingga menjadi klausa sematan, semakin mempersulit responden untuk menerjemahkannya dengan baik dan benar.

\section{SIMPULAN DAN SARAN}

Berdasarkan penjelasan di atas, nyata bahwa kemampuan mahasiswa dalam menerjemahkan masih perlu ditingkatkan, terbukti dari tingginya tingkat kesalahan penerjemahan yang ditunjukkan dalam penelitian ini. Faktor kesalahan serta penyebab tersebut menunjukkan betapa pentingnya peningkatan penguasaan mahasiswa Prodi Bahasa Jepang terhadap tata bahasa Jepang dan bahasa Indonesia dan perlu segera ditindaklanjuti. Untuk menghasilkan terjemahan baik dan benar, mahasiswa harus memiliki pemahaman yang menyeluruh tentang sintaksis dan semantik kedua bahasa, baik Bsu maupun Bsa. Oleh karena itu, materi tata bahasa perlu dikembangkan dengan menambah materi tentang kalimat majemuk bahasa Jepang, bahasa Indonesia, serta latihan untuk pengayaan.

Pemberian materi tersebut dapat dimulai dari mata kuliah Tata Bahasa tingkat dasar hingga menengah, dan 
dilakukan secara berkelanjutan. Adapun untuk latihan atau praktik pemahaman kalimat majemuk dan makna kata, dapat dilakukan pada mata kuliah Membaca, dengan level materi yang disesuaikan dengan materi Tata Bahasa. Selanjutnya, mata kuliah Penerjemahan dapat menjadi media untuk berlatih menerjemahkan kalimat majemuk sebanyak-banyaknya, mengingat teks-teks dalam bahasa Jepang banyak menggunakan jenis kalimat ini. Dengan demikian diharapkan kesalahankesalahan penerjemahan, khususnya penerjemahan kalimat majemuk, dapat diminimalisir dan ditingkatkan kualitasnya.

\section{DAFTAR PUSTAKA}

Alwi, Hasan., dkk. (2003). Tata Bahasa Baku Bahasa Indonesia (Edisi Ketiga). Jakarta: Balai Pustaka.

Larson, Mildred L. (1988). Penerjemahan Berdasar Makna: Pedoman untuk Pemadanan Antar Bahasa (Terjemahan). Jakarta: Arcan.

Masao, Hamano. (1977). Beetoben: Kodomo no Denki Zenshuu.
Masahiko, Minami (Ed.). (2016). Handbook of Japanese Applied Linguistics. Boston: Walter de Gruiter Inc.

Muhlisian, Asep Ahmad. (2013). Analisis Kesalahan Penerjemahan Bahasa Jepang dalam Karya Ilmiah Mahasiswa S2 (Tesis). Bandung: Universitas Pendidikan Indonesia (Tidak Diterbitkan).

Newmark, Peter. (1988). A Textbook of Translation. Hertfordshire: Prentice Hall Int. Ltd.

Nitta, Yoshio. (2008).Gendai Nihongo Bunpo-6: Fukubun.Tokyo: Kuroshio Shuppan.

Presada, Diana., Mihaela Badea. (2014). "The Effectivenes of Error Analysis in Translation Classes: Pilot Project". Porta Linguarum (hal. 49-59).

Sutedi, Dedi. (2003). Dasar-dasar Linguistik Bahasa Jepang. Bandung: Humaniora.

Tomomatsu, Emoto., dkk. (2007). Donna Toki Dou Tsukau: Nihongo Hyougen Bunkei. Tokyo: Aruku. 